\title{
SUSTAINABLE AIRLINE WASTE MANAGEMENT: A CASE STUDY OF AIR NEW ZEALAND'S WASTE MANAGEMENT PROGRAMS AND STRATEGIES
}

\author{
Glenn Baxter ${ }^{1}$ \\ ${ }^{1}$ School of Tourism and Hospitality Management, Suan Dusit University, Huahin Prachaup Khiri Khan, \\ Thailand
}

Received 4 April 2020; accepted 22 June 2020

\begin{abstract}
Waste management and waste disposal are now regarded as being amongst the most significant issues in the environmental management of the global airline industry. Consequently, airlines are now making substantial efforts to improve their waste management and reduce waste generation. Using an instrumental case study research approach, this study examines Air New Zealand's environmentally sustainable waste management programs and strategies. Air New Zealand launched its "Project Green” waste program in 2017. Since its inception, the "Project Green" waste management program together with other waste-related strategies have enabled the airline to mitigate the environmental impact of its annual wastes, especially those disposed to landfill. Air Each year, Air New Zealand generates a heterogeneous range of organic and in-flight service wastes. A major challenge confronted by the airline, in reducing waste to landfill, is the apparent shortage of recycling and composting infrastructure available for the airline to send its waste material to. More robust infrastructure across New Zealand would assist Air New Zealand to keep compostable and recyclable waste out of landfills.
\end{abstract}

Keywords: airlines, Air New Zealand, case study, recycling, re-used wastes, sustainable waste management, waste to landfill.

\section{Introduction}

Strategic waste management plans are now frequently being used by firms to manage waste problems. Around the world, firms are adopting a zero waste strategy; this strategy aims to prevent waste through sustainable design and consumption practices together with the optimum recovery from waste and avoiding the necessity to dispose of waste by incineration or landfills wherever possible (Zaman and Ahsan, 2020). The zero-waste concept includes waste prevention; high levels of recycling and the recovery of all resources from waste; as well as behavioural change (Cole et al., 2014). Uz Zaman (2014, p. 682) has noted that zero waste management is a holistic waste management concept that views waste as a resource which is produced at the intermediate phase of the firm's resource consumption process. Indeed, zero waste management is a whole system approach that is centered around reducing, re-using, and recycling of wastes. The objective of a zero-waste strategy is to optimize recycling, minimize waste,

${ }^{1}$ Corresponding authorg_glennbax@dusit.ac.th 
reduce the consumption of materials, ensuring that products are produced that can be re-used, repaired, and recycled, and the purchasing of sustainable products. Zero waste management systems reduce greenhouse gases through energy savings, particularly by reducing energy consumption associated with the extraction, processing and transportation of raw materials and waste, and by reducing and eventually eliminating the requirement for landfills and incineration of waste (Rathoure, 2020).

Environmental sustainability is viewed as being a critical element of sustainable development. Environmental considerations in relation to waste have become increasingly important due to population growth and the increased production of a wide variety of products (Erickson, 2016). Furthermore, future limitations on the availability of selected resources underpins the requirement for increased material efficiency. In addition, in a climate-constrained world the impact of resource use on greenhouse gas emissions needs to be significantly minimized. Waste management is thus regarded as the key to achieving sustainable resource management (Corsten et al., 2013).

Air transport operations inevitably have a significant impact on the environment (Daley, 2016; Kumar et al., 2020; Schäfer and Waitz, 2014). In recognition of this environmental impact, airlines have become increasingly committed to becoming more "green," or environmentally friendly (Hagmann et al., 2015; Mayer et al., 2012). Solid waste management and waste disposal is regarded as being one of the most significant issues in the environmental management of the global airline industry (Li et al., 2003). Each year the air transport industry generates a substantial amount of comingle waste (Blanca-Alcubilla et al., 2019). The International Air Transport Association (IATA), the peak global airlines association, has estimated that in 2018 approximately 6.1 million tonnes (6.7 million US tons) of waste were generated onboard aircraft (Moynihan and Moynihan, 2019). According to IATA (2020a), around $20 \%$ was food and drinks that were unused during flights (International Air Transport Association, 2020b; Rueb, 2019). Consequently, airlines are making considerable efforts to improve waste management and reduce waste generation (Blanca-Alcubilla et al., 2019; Moynihan and Moynihan, 2019).

Air New Zealand was selected as the case airline as it an airline that has placed a very high focus and commitment to the sustainability of its operations. A key element of the company's sustainability framework is its commitment to reducing waste through its "Project Green" program, which was launched in 2017 (Air New Zealand, 2019a). The objective of this study is to examine how Air New Zealand sustainably manages its wastes and how it works with other key stakeholders participating in the "Project Green” waste management program to mitigate its annual waste production. The study also aims to identify the types of waste generated by Air New Zealand and the challenges that it may confront in handling the waste in a sustainably environmental manner.

The remainder of the paper is organized as follows: the literature review presented in Section 2 provides an overview of waste management systems, the waste management hierarchy, and the types and sources of airline waste. The research method that underpinned the study is described in Section 3. The empirical examination 
of Air New Zealand's sustainable waste management programs and strategies are presented in Section 4. The key findings of the study are presented in Section 5.

\section{Background}

\subsection{Components of a Waste Management System}

Waste is produced from industrial activities, which is frequently directly associated with a firm's production or the waste is generated at the end of the life cycle of certain products (Pharino, 2017). According to Demirbas (2015, p. 1280), "waste management is the collection, transport, processing, recycling or disposal, and monitoring of waste materials". Waste management is a part of the generation, collection and a firm's waste disposal system (Seadon, 2010). A firm's typical waste management system consists of the collection, transportation, pre-treatment, processing (Christenson, 2010), and final abatement of residue wastes. The waste management system is comprised of the whole set of activities that are required for the handling, treatment, disposal or recycling of the waste materials by a firm (Demirbas, 2015).

Many modern waste treatment processes and waste management systems can treat many different types of waste simultaneously. These systems also deliver some very useful outputs for firms, for example, secondary materials and energy (Heijungs and Guinée, 2007).

\subsection{The waste Management Hierarchy}

The waste management hierarchy often varies in its exact form but it typically ranks waste management options in a preferred order: waste minimization, re-use of waste, materials recycling, biological treatment, incineration with energy recovery, and the disposal of waste to landfill (Nordone et al., 2009, p. 93). The waste management hierarchy is as follows: reduce, re-use, recycle, recovery and disposal (Figure 1) (Baxter et al., 2018a; Davies, 2016). This means that in the waste management hierarchy, reducing waste should be the primary objective of a company. There are two key principles in a company being able to successfully achieve waste reduction. First, the company should aim to reduce the volume generated and disposed of in landfills, therefore reducing the deterioration of the environment, reducing the emissions generated from landfills and also providing energy and natural resources savings ( $\mathrm{Zhu}$ et al., 2008). Secondly, a company should adopt an effective system to manage all unavoidable waste. According to the waste management hierarchy, re-use and recycling of waste are the best methods of handling unavoidable waste (Pitt and Smith, 2003). Re-using waste, wherever possible, is regarded as more favorable to recycling. This is because the waste items do not need to be processed prior to being used once again (Güren, 2015). The next best waste disposal route is that of incineration. The incineration of solid waste has two very useful purposes in a waste management system. Principally, it reduces the volume of waste to be disposed of by sanitary landfill (Rand et al., 2000). Secondly, incineration can also be used as a means of generating energy (Awasthi et al., 2019; Hettiarachchi and Kshourad, 2019).

Finally, disposal in landfill sites is regarded as the least desirable option (Manahan, 2011; Pitt and Smith, 2003). Waste that is disposed of through landfilling and open dumping, is regarded as being environmentally unsafe due to emission of greenhouse gases (GHGs) (Ahmed et al., 2020; Trabold and Nair, 2019). 


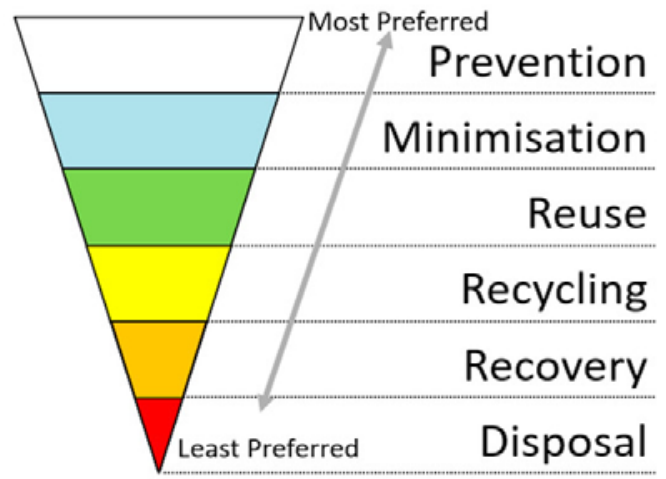

Fig. 1.

The Waste Management Hierarchy

Source: adapted from European Commission (2019)

\subsection{The Types and Sources of Airline Waste}

Airlines produce large volumes of waste which typically includes food and drink containers, newspapers and magazines, food waste (from offices, lounges/cafeterias), light bulbs, printer toner, paper, documents and computer print outs. In addition to the waste generated from their administration and flight operations, many airlines generate considerable waste from handling their air cargo services. These wastes include tires, fluids, lights bulbs, batteries, wood and wooden pallets, plastic wrapping material, green waste from lawn/garden care and landscaping, paper, and computer printouts (Baxter et al., 2018b).

Deplaned aircraft waste is waste that originates on an airline's flights. Cabin waste is comprised of two principal streams: cleaning waste and catering (galley) waste (International Air Transport Association, 2020a). Cleaning waste is leftover rubbish from items provided to passengers on the aircraft during their flight. These items include newspapers, paper towels, plastic bottles (United States Federal Aviation Administration, 2013), food dropped on the floor, amenity kits and plastic wrapping from blankets, pillows and headsets. Cleaning waste also includes the contents of washroom bins and medical waste such as used syringes that have been left by passengers for subsequent disposal. Catering (galley) related waste comes from inflight meals, snacks and beverages served to passengers throughout the flight. This waste can also consist of leftover food, drinks and packaging which is placed back in the service trolleys, in static or compactor bins. Importantly, this waste can contain large volumes of liquid from unconsumed beverages and ice. (International Air Transport Association, 2020a).

The type of meals served by an airline on its flights varies according to the duration of flight. Consequently, the quantity and content of the generated waste stream is closely related to the length of the flight (Chandrappa and Das, 2012; El-Mobaidh et al., 2006). 


\subsection{The Airline Waste International Regulatory Framework}

All cabin waste is subject to national waste management controls that limit pollution (International Air Transport Association, 2020a). Indeed, many countries have imposed very stringent health and safety regulations in place for in-flight waste (Moynihan and Moynihan, 2019). Furthermore, many countries have gone further with their regulations, introducing restrictions on catering waste from international flights to protect their agricultural sector (in respect to animal health) (International Air Transport Association, 2020a). Airline meals are also prepared using stringent hygiene and quality control standards (Jones, 2004; Sheward, 2006). The regulations often result in the incineration of all cabin waste with limited potential for reuse and recycling (International Air Transport Association, 2020a). Thus, as international flights are subject to strict Customs and biosecurity standards; these standards and regulatory requirements add a high degree of complexity as to how an international airline can handle the waste generated on their international services (Air New Zealand, 2019c). Governments around the world also typically legislate the requirements for the handling of general and hazardous wastes as well.

\section{Research Methodology}

\subsection{Research Approach}

The research approach underpinning this study was based on an instrumental case study approach. An instrumental case study is the study of a case, for instance, a company, that provides insights into a specific issue, redraws generalizations, or builds theory (Baxter; 2019; Stake, 1995, 2005). The goal of the case study approach is to expand and build theories rather than perform statistical analysis to test a study's specific hypothesis (Rahim and Baksh, 2003). In addition, the present study was designed around the established theory of sustainable waste management (Chang and Pires, 2015; Pires et al., 2019).

\subsection{Data Collection}

Data for the study was obtained from a range of documents: Air New Zealand's annual sustainability reports, Air New Zealand's annual reports, and media releases, airline industry press articles, and company materials available on the internet. These documents provided the sources of the study's case evidence. An exhaustive source of the leading air transport and waste-related journals and magazines was also conducted. The study also included a search of the SCOPUS and Google Scholar databases.

The key words used in the database searches included "Air New Zealand sustainability policy”, "Air New Zealand Project Green program”, "Air New Zealand engagement with key waste management stakeholders", "types of waste produced by Air New Zealand", and "Air New Zealand sustainable waste management challenges".

Secondary data was therefore used in the study. The three principles of data collection as recommended by Yin (2018) were followed: the use of multiple sources of case evidence, creation of a database on the subject and the establishment of a chain of evidence. 


\subsection{Data Analysis}

The empirical data collected for the case studies was examined using document analysis. Document analysis is regularly used in case studies (Grant, 2019; Monios, 2016) and focuses on the information and data from formal documents and company records that have been gathered by the researcher(s) (Baxter, 2019; Ramon Gil-Garcia, 2012). The documents gathered for the study were examined and assessed by four key criteria: authenticity, credibility, representativeness and meaning (Fulcher and Scott, 2011; Scott and Marshall, 2009).

Prior to commencing the formal analysis of the documents that were gathered for the study, the context in which the documents were created was established and the authenticity of the documents was assessed. In document analysis, authenticity involves an assessment of the gathered documents for their soundness and authorship. Scott and Marshall (2009, p.188) note that "soundness refers to whether the document is complete and whether it is an original and sound copy". Authorship of documents relates to such issues as collective or institutional authorship. In this study the source of the case study documents was Air New Zealand. The documents were available in the public domain. The credibility criterion concerns the accuracy and sincerity of a document (Fulcher and Scott, 2011; Scott and Marshall, 2009). In the present study, the evidence for the case study was corroborated using various kinds of documents (Baxter, 2019), for example, Air New Zealand's annual reports, sustainability reports, and media releases. The representativeness criterion involved an assessment of the availability and survival of the documents gathered. There were no major difficulties in obtaining documents for the study as all the relevant documents could be readily accessed in the public domain. The fourth criterion, meaning, is a most critical aspect of document analysis and occurs at two levels. The first is the literal understanding of a document, by which is meant its physical readability, the language used and whether it can be read, and secondly, the date of the document (Fulcher and Scott, 2011; Scott and Marshall, 2009). When conducting document analysis in a study, it is important to interpret the understanding and the context within which the document was produced. This enables the researcher to interpret the meaning of the document. The evidence found in the documents gathered and used for the study were all clear and comprehensible (Baxter, 2019; van Schoor, 2017).

Following the guidance of Yin (2018), all the collected documents were downloaded and stored in a case study database. The documents gathered for the study were all in English. Each document was carefully read, and key themes were coded and recorded. The study also followed the recommendation of van Schoor (2017) who has observed that in order to avoid bias entering a study, documents from different sources should also be carefully analyzed. Thus, in the present study, documents were collected from multiple sources. This triangulation approach helped verify the themes that were detected in the documents gathered in the study (Baxter, 2019; Kitamura, 2019).

\section{Results}

\subsection{A Brief Overview of Air New Zealand}

Established in April 1940, Tasman Empire Airways Limited (TEAL) was originally 
owned by the New Zealand (50\%), Australian (30\%) and British (20\%) governments. The airline's inaugural flight took place on 10 April 1940 linking Waite Harbour, Auckland and Rose Bay in Sydney. The first flight was operated with a Short S30 flying boat (Chant, 1997). On 1 April 1965, the airline's named changed to Air New Zealand. This was to reflect a major international expansion (Brimson, 1985; Green and Swanborough, 1975).

Air New Zealand was initially privatized by the New Zealand government in 1989 (Duval, 2005). Air New Zealand's privatization contained foreign ownership limits, that is, $49 \%$ overall or $25 \%$ from any single airlines, and 35\% from any group of airlines (Morrell, 2013). In October 2001, the New Zealand Government agreed to invest \$NZD 885 million into Air New Zealand (Gaynor, 2015), who was experiencing some difficulties at that time (Newberry, 2011). This initiative comprised a $\$ N Z D$ 300 million loan, in the form of convertible preference shares, and the purchase of new shares valued at \$NZD 585 million. The convertible preference shares were subsequently converted into ordinary shares in 2005. In 2004, Air New Zealand placed a rights issue at $\$ N Z D 1.30$ a share and the New Zealand Government purchased a further \$NZD 150 million worth of new shares (Gaynor, 2015). At the time of the present study, the New Zealand Government owned 52\% of Air New Zealand ordinary shares. The remaining shares are listed on the NZ Stock Exchange (ticker symbol AIR.
NZ) and on the Australia Stock Exchange (ticker symbol AIZ.AU) (Air New Zealand, 2020c).

Today, the Air New Zealand Group (Air New Zealand) operates a global network providing both air passenger and air cargo services to, from and within New Zealand. Air New Zealand's strategic focus and its competitive advantage lies within the Pacific Rim where the company's route network reach extends from New Zealand into Australia, Asia and the Americas (Air New Zealand, 2019b). As at 30 September 2019, Air New Zealand's operated a fleet of 116 aircraft (Air New Zealand, 2020b).

Figure 2 presents Air New Zealand's total annual revenue passenger kilometres performed (RPKs) and total enplaned passengers for the period 2011 to 2019. Revenue passenger kilometres are a distant weighted measure because they are produced by an airline flying one passenger one kilometre. One passenger enplanement measures the embarkation of a revenue passenger, whether originating, stop-over, connecting or returning (Holloway, 2016). Air New Zealand's total annual RPKs and annual enplaned passengers grew from 269.9 million RPKs and 13.1 million passengers in 2011 to 385.7 million RPKs and 17.7 million enplaned passengers in 2019 respectively, as illustrated in Figure 2. Also, as can be observed in Figure 2, there has been a consistent growth in both RPKs and enplaned passengers during the period 2011 to 2019. 


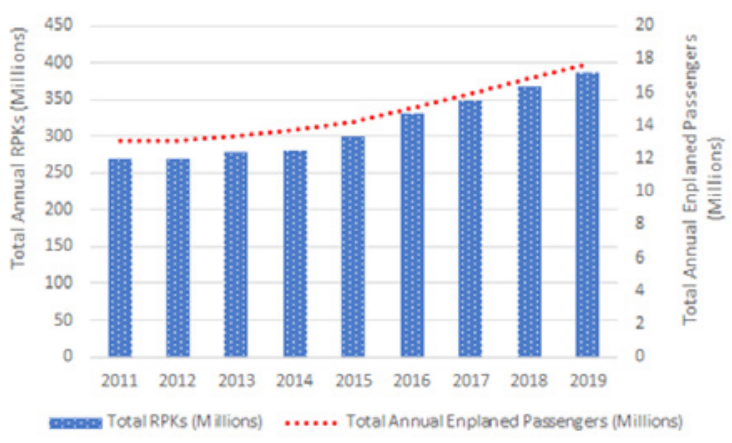

Fig. 2.

Air New Zealand's Total Annual Revenue Passenger Kilometres Performed (RPKs) and Total Annual Enplaned Passengers: 2011-2019

Source: data derived from Air New Zealand (2015a,2019b)

\subsection{Air New Zealand Sustainability Policy}

Air New Zealand's purpose is to substantially boost New Zealand's success - socially, environmentally, and economically. The airline's "Sustainability Framework" (Table 2) helps guide the company's actions and is aligned with the United Nations Sustainable Development Goals (SDGs) (Air New Zealand, 2019c). The United Nations Sustainable Development Goals (SDGs) provide a framework for business and government to solve global economic, social, and environmental challenges (Air New Zealand, 2018).

Air New Zealand has identified nine SDGs which they believe that the company has the greatest ability to positively impact (Table 2) (Air New Zealand, 2019c). As can be seen in Table 2, Air New Zealand's first SDG is titled "Manaakitanga', "Our people", and the focus of these SDGs is on Air New Zealand employees as well as the broader community. Air New Zealand has incorporated 6 of the United Nations SDGs into this part of their
Sustainability Framework. The second part of the company's Sustainability Framework is titled "Kaitiakitanga", "Our place", and the focus here is on carbon abatement, as well as nature and science. This part of the Sustainability Framework is based on four of the United Nations SDGs (Table 1). The final part of Air New Zealand's Sustainability Framework is titled "Ōhanga Ora", "Our economy", and its focus is on sustainable tourism trade, and enterprise. This part of the Sustainability Framework includes the United Nation's SDGs Number 8 Decent work and economic growth, and Number 12 Responsible consumption and production (Table 2) (Air New Zealand, 2019c).

Air New Zealand has established a fourmember Sustainability Executive Steering Group. This group is comprised of the company's executives responsible for Strategy, Networks and Alliances, Ground Operations, Marketing and Customers, and Operations Integrity and Standards. This group steers the company's sustainability agenda and drives change through their 
respective parts of the business. Internally the company uses an online sustainability dashboard to regularly monitor and track its performance against targets in each of its framework areas (Air New Zealand, 2019c).

Air New Zealand has also established a "Sustainability Advisory Panel" which brings together an internationally renowned group of experts who have been selected for their skills, expertise and ability to challenge the company's sustainability agenda. The advisory panel has six members and are joined by Air New Zealand's Chief Executive and Chief Strategy, Networks and Alliances Officers. The Advisory Panel and other company representatives meet twice a year to discuss progress, identify emerging issues and develop responses for the issues identified. The Panel are also consulted on issues identified outside of the regular meetings (Air New Zealand, 2019c).

\section{Table 1}

Air New Zealand Sustainability Framework

\begin{tabular}{|c|c|c|}
\hline $\begin{array}{c}\text { Manaakitanga } \\
\text { Our People }\end{array}$ & $\begin{array}{c}\text { Kaitiakitanga } \\
\text { Our Place }\end{array}$ & $\begin{array}{c}\text { Ohanga Ora } \\
\text { Our Economy }\end{array}$ \\
\hline (3) Good health and well-being & (7) Affordable and green energy & $\begin{array}{c}\text { (8) Decent work and economic } \\
\text { growth }\end{array}$ \\
\hline (5) Gender equality & $\begin{array}{c}\text { (12) Responsible consumption and } \\
\text { production }\end{array}$ & $\begin{array}{c}\text { (12) Responsible consumption and } \\
\text { production }\end{array}$ \\
\hline $\begin{array}{c}\text { (8) Decent work and economic } \\
\text { growth }\end{array}$ & (13) Climate action & \\
\hline (10)) Reduced inequalities & (14) Life below water & \\
\hline (13) Climate action & & \\
\hline (15) Life on land & & \\
\hline
\end{tabular}

Source: Air New Zealand (2019c)

\subsection{Air New Zealand "Project Green" Waste Management Program}

In 2017, Air New Zealand, its in-flight catering partner LSG Sky Chefs, and the Ministry for Primary Industries (MPI), joined forces to address the inflight waste from Air New Zealand's international services arriving at the airline's primary hub at Auckland International Airport (Air New Zealand, 2017a). The waste initiative program was developed over 18 months with Air New Zealand working closely with LSG Sky Chefs and New Zealand's Ministry for Primary Industries during this time. The "Project Green" waste management program required a change in the airline's onboard processes, especially for cabin crew who play a key role by returning unused items to stowage and separating goods correctly (Air New Zealand, 2017a; Creedy, 2017).

Prior to the implementation of the "Project Green" waste management program, New Zealand's Biosecurity regulations required any unopened food left over from international flights to be disposed by landfill to be burned or buried (Creedy, 2017; Vezich, 2017). The key objective of the "Project Green" waste management program is to divert 150 tonnes of waste from landfill annually (Bradley, 2019; Gavine, 2017). The "Project Green" waste management program was one of many initiatives Air New Zealand 
had in place at the time of its implementation to reduce waste, with other programmes addressing organic waste from office spaces, the repurposing of office materials and lounge furniture, and blankets (Air New Zealand, 2017a; Airside International, 2018).

During 2017, the "Project Green" waste management program enabled 40 Air New Zealand inflight products that were previously disposed by landfill due to biosecurity controls, to be reclassified so that these items could be reused on future flights if removed from an aircraft sealed and untouched (Air New Zealand, 2017a). Products approved under the scheme include sealed beverages and snacks (for example, cans of soft drink, packets of cookies, boxes of tea, packets of coffee and sugar sachets). As at October 2019, the airline had repurposed more than one million of each of the following - plastic cups, sugar sticks, paper cups and paper cup lids (Bradley, 2019). Also, during 2017, new waste management infrastructure enabled wax coated inflight coffee cups to be recycled in certain parts of New Zealand. Air New Zealand, tested coffee cup recycling on its domestic services. A trial was conducted on its services to Dunedin and this showed that the airline could double its inflight recycling rate and remove cups out of the landfill waste stream. Air New Zealand noted that by rolling this initiative out across its domestic fleet the initiative would allow it to recycle 6.5 tonnes of café cups, plastic glasses and water bottles per year (Air New Zealand, 2017b).

In 2018 , to meet its waste management targets, Air New Zealand asked potential suppliers to partner with the airline on a more strategic approach to meeting its waste reduction targets. To drive this systemic change, Air New Zealand have noted that new supply contracts must include shared financial incentives and landfill reduction targets (Air New Zealand, 2018).

In June 2019, Air New Zealand partnered with New Zealand-based, family-owned company "Twiice" to trial its edible biscotti coffee cups. This initiative was also part of Air New Zealand's objective to further reduce in-flight waste. The concept was to make the cups edible. Air New Zealand serves around 8 million cups of coffee cups each year, so by making cups edible the airline could reduce the number of cups that would need to be disposed by landfill. The cups were made of wheat flour, sugar, egg, and vanilla, and was basically a cup-shaped vanilla cookie (Smith, 2019).

In July 2019, Air New Zealand set a target to increase the number of single-use plastic items it would remove in 2019 from 24 million to nearly 55 million items. Also, in 2019, to mark the airline's "Plastic Free July" campaign, Air New Zealand removed individual plastic water bottles from its Business Premier and Premium Economy aircraft cabins on its Trans-Tasman and Pacific Island services under five hours in duration (Air New Zealand, 2019c; Green Air, 2020). This project was also targeted at the airline's "Works Deluxe" product offering on those flights. The initiative was anticipated to divert more than 460,000 bottles that would have to be sent annually to landfill and save over 300 tonnes of carbon emissions by reducing weight on the operating aircraft (Green Air, 2020). More than 600 Air New Zealand staff took part in the employee-led "Plastic Free July" campaign. The airline's staff took the challenge to reduce their usage of single-use plastic very seriously. To reward this commitment, Air New Zealand offered their staff some prizes. One of the most 
noteworthy examples was the airline's team based in Samoa, who arranged a fully catered meal to celebrate "Matariki" in traditional style using zero plastics (Air New Zealand, 2019c).

In 2019, Air New Zealand also announced plans to roll out coffee cups made from plants rather than plastic across its domestic and international networks from October 2019 , while plastic water cups were to be transitioned to recyclable alternatives from September 2019. Air New Zealand had previously targeted coffee and water cups on its domestic network, as this was where most cups are used. However, in 2019 the scope was expanded to introduce the lower impact cups across the airline's international network. This initiative resulted in the total number of cups being replaced from 14.7 million to 44.5 million. Individual plastic sauce packets were also removed from the airline's Business Premier cabins on its mainland North America and Hong Kong services, and these items were eliminated entirely from the global network by the end of October 2019 (Green Air, 2020). The airline's passengers were instead served sauce in reusable dishes, which was predicted to prevent around 200,000 plastic packets going to landfill each year (Air New Zealand, 2019c; Green Air, 2020; Smith, 2019). Also, in 2019, Air New Zealand set an objective to reduce its plastic footprint by 260,000 plastic toothbrushes, 3,000 straws, 7.1 million stirrers, and 260,000 eye mask wrappers. A key challenge was to identify alternatives to plastic that are genuinely biodegradable or recyclable, whilst also being lightweight (Bradley, 2019). In July 2019, Air New Zealand rolled out its "Project Green" waste management program in Wellington and Christchurch, which was followed by Queenstown in August 2019. The "Project
Green" waste management initiative was also introduced in Los Angeles, the airline's largest offshore catering airport. This was done in conjunction with Air New Zealand's partner LSG Sky Chefs. This was the first time the "Project Green" waste management had been implemented outside of New Zealand. Based on trials at the four new locations, Air New Zealand expected to divert around 111 tonnes of product from landfill annually. The cost savings from not having to pay landfill charges are being reinvested on other sustainable supply chain initiatives, with less product waste being disposed to landfill. In addition, by only transporting what food/materials the airline requires to deliver its in-flight services the weight of the operating aircraft is reduced, and this helps to reduce fuel burn and carbon emissions (Air New Zealand, 2019c).

During 2019, Air New Zealand subsequently changed its waste management contractor. This has resulted in new ways for the two firms to collaborate to more sustainably manage the wastes generated by Air New Zealand. Waste Management NZ Limited assumed co-responsibility for delivering on Air New Zealand's public waste targets and the firm is providing full-time, inhouse resources to work with the airline on minimising waste at source. The two firms have taken an entire process holistic approach, from production through procurement to product end-of-life (Air New Zealand, 2019c).

By February 2020, the "Project Green" waste management program had enabled Air New Zealand to recover 85 tonnes of water bottles, in excess of 11.5 million plastic glasses, and more than 4 million sugar sticks (Young, 2020). During 2020, Air New Zealand also planned to introduce the 
"Project Green" waste management program in San Francisco, Chicago, and Houston (Air New Zealand, 2019c).

One of the key benefits for Air New Zealand from its "Project Green" waste management program is that the airline is achieving cost savings by not biosecurity treating the products and then being required to pay the applicable landfill charges. A further benefit has been that of staff engagement (Bradley, 2019). In addition to reducing the amount of waste disposed to landfill, the data captured by Air New Zealand has resulted in the company being better able to assess flight loading requirements and also to identify other opportunities to reduce waste at the source (Young, 2020).

\subsection{The Types of Waste Produced by Air New Zealand}

As previously noted, on an annual basis Air New Zealand generates a diverse range of wastes. Organic wastes are produced from the airline's head office, office materials and lounge furniture, staff uniforms and blankets are other types of wastes produced from its operations and from its administration activities (Air New Zealand, 2017b). Other types of waste, which are primarily produced from in-flight services, include plastic cups, sugar packets, bottled water (Air New Zealand, 2017a), plastic toothbrushes, straws, million stirrers, eye mask wrappers, soft drink cans, packets of cookies, boxes of tea, and packets of coffee (Bradley, 2019).

\subsection{The Annual Waste Disposed by Landfill and Waste Minimization Initiatives by Air New Zealand}

In 2015, Air New Zealand's waste minimisation program continued to make progress, with recycling rates from the airline's New Zealand ground sites reaching $65 \%$ (Table 2), which was up from $32 \%$ in 2013. In 2015, the highest rates of waste diversion occurred at the airline's Auckland and Christchurch engineering bases, where employees had implemented major recycling initiatives that diverted approximately $71 \%$ of waste. In 2015, Air New Zealand commenced donating unbranded blazers, trench coats, trousers and merino knitwear to charities, which included the Women's Refuge and the Auckland City Mission. Uniform garments that could not be reused due to their condition or because of branding and security risks, were being shredded and converted into furniture blankets and bedding felt. The airline estimated that its uniform reuse and recycling programmes saved approximately 6.4 tonnes per year of material being disposed to landfill (Air New Zealand, 2015b).

In 2016, Air New Zealand exceeded its target to divert $70 \%$ of its domestic ground waste from landfill with $73 \%$ of waste being diverted, a $2.81 \%$ increase on the 2015 levels (Table 2). Also, in 2016, the airline set a zero waste to landfill target for all Auckland ground sites by 2020. Air New Zealand achieved a waste recycling rate of $74 \%$ in 2016 . Air New Zealand's reuse and recycling programme for its corporate uniforms continued in 2016, with seven tonnes of textile waste estimated to have been diverted from landfill throughout the year. The airline also collaborated with the "R\&D Company", "The Formary" and other New Zealand firms to explore long term solutions for textile re-use. Following a series of office refits during 2016, Air New Zealand donated 1,500 pieces of used office furniture to Fijian schools, which were being rebuilt following Cyclone Winston, with a 
further 1,650 pieces of furniture donated to 14 community groups and not-for-profit organisations. In 2016, Air New Zealand also continued to support Auckland International Airport's waste minimisation initiative for non-food cabin waste on inbound flights arriving at the airport. This project was initiated by the Air New Zealand "Cleaning Team and Operations Delivery Team”, who foresaw an opportunity to re-introduce unused products back onto the airline's flights. During 2016, the team worked with Auckland International Airport's waste management contractor "OCS WasteLine", who processed cabin waste and isolated Air New Zealand products. As this program gained momentum, Air New Zealand established an Inflight Waste and Recycling team comprising cabin crew representatives, who focused on encouraging fellow crew members to raise awareness and return unused items back to their allocated stowage positions. This avoided product being disposed to landfill. For the financial year ending June 2016, the project achieved landfill diversion rates of almost $48 \%$ through the recycling of dry waste products that posed no biosecurity risks (Air New Zealand, 2016).

During 2017, Air New Zealand's landfill waste diversion rate was $71 \%$, which was $2.73 \%$ lower than the rate achieved in 2016 (Table 2). In 2017, Air New Zealand introduced an organic waste collection system at its Auckland head office, which helped improve landfill diversion rates by $9 \%$ percent (13 tonnes of organic waste being diverted from its Head Office site). Following the implementation of this initiative at its Head Office in Auckland, the airline decided to implement organic waste collections at other major employee sites during 2018. The airline also established new waste targets for all its sites. In addition, Air New Zealand investigated new technology opportunities, and focused on improved internal communications to enable information sharing so that employees could play their part in driving a culture of waste minimisation throughout the company. During 2017, Air New Zealand continued to recycle uniforms and furniture that were no longer fit for purpose but could be beneficial to non-profit organizations. Approximately five tonnes of uniforms were recycled thus avoiding disposal to landfill. In addition, over 500 pieces of furniture were distributed to not-for-profit organizations in Auckland, New Zealand as well as to Fiji. The refurbishment of Air New Zealand's Melbourne Airport office during 2017 resulted in the reuse of existing good quality kitchen and office components, and the donation of desks and screens to community groups (Air New Zealand, 2017b).

During 2018, Ai New Zealand introduced a wider set of waste reduction targets. As can be observed in Table 2, the total waste disposed by landfill (\%) was $69.1 \%$ down from the $70.5 \%$ recorded in the preceding year. This decline of $2.67 \%$ (Table 2), could be attributed to a variety of factors. In 2018, there was an increase of $13.5 \%$ (336 tonnes) of waste generated compared to 2017 from both inflight and ground operations. This increase in waste can be partly attributed to a $6.4 \%$ increase in enplaned passenger numbers, and increased volumes of procured product. Also, in 2018, Air New Zealand, increased the number of waste managed ground sites, to include airport lounges as well as offices and passenger terminals. Following trials during 2018, which resulted in a $14 \%$ increase in diversion from landfill, Air New Zealand also invested in additional organic waste infrastructure and services 
located at its major employee ground sites. The objective of this approach was to help separate more volumes of waste at source. Air New Zealand also increased staff engagement on the issue of waste generation and separation at source. This was supported by the company's Properties team extending the company design manual from customer-facing lounges to all parts of the organisation, including for infrastructure, such as, recycling bins, signage and fixtures (Air New Zealand, 2018).

In 2019, Air New Zealand focused on reducing the volume of waste and plastic packaging that the airline purchased at source. This strategy ensured that Air New Zealand was less reliant on having the appropriate end-of-life facilities in place. Also, during 2019, the types of products that could be disposed by landfill through recycling systems decreased substantially. Previously the airline was able to recycle seven discrete types of plastic at existing $\mathrm{New}$ Zealand facilities, however, this changed to just two recyclable products in 2019 (Air New Zealand, 2019c). Table 2 shows that the annual waste disposed by landfill declined by $1.30 \%$ on the 2018 level.

During 2020, Air New Zealand planned to renew its focus on working closely with its pool of 4,000 suppliers in order to drive changes in the packaging of products, including some customer-favourite inflight products (Air New Zealand, 2019c).

Table 2

Air New Zealand Annual Waste Disposed by Landfill (\%) and Year-on-year Change: 2015-2019

\begin{tabular}{|c|c|c|}
\hline Year & $\begin{array}{c}\text { Percentage of Waste } \\
\text { Disposed to Landfill }\end{array}$ & Year-on-Year Change (\%) \\
\hline 2015 & 71.0 & 0 \\
\hline 2016 & 73.0 & 2.81 \\
\hline 2017 & 71.0 & -2.73 \\
\hline 2018 & 69.1 & -2.67 \\
\hline 2019 & 68.2 & -1.30 \\
\hline
\end{tabular}

Source: data derived from Air New Zealand (2015b, 2016,2017b, 2019c)

\subsection{The Waste-related Challenges Experienced by Air New Zealand}

At the time of the present study, Air New Zealand was working on ways to further segregate the waste that is collected inflight, for instance, soft plastics and compostable waste. A major challenge confronted by the airline, however, in reducing waste to landfill, is the apparent shortage of recycling and composting infrastructure available for Air New Zealand to send its waste material to. More robust infrastructure across $\mathrm{New}$ Zealand, including in the regions, would assist Air New Zealand to keep compostable and recyclable waste out of landfills (Air New Zealand, 2020a; Young, 2020). Consequently, at the time of the present study, Air New Zealand was investigating the types of products that it purchases to ensure these can be processed in existing New Zealand waste facilities.

In New Zealand there is only one polyethylene terephthalate (PET) manufacturer, which potentially restricts the airline's ability to environmentally dispose of such items. Also, during 2018, Air New 
Zealand was no longer able to send the volume of fabric type used in the company's uniforms to local textile recycling plants (Air New Zealand, 2018).

\section{Conclusions}

This paper has examined Air New Zealand's environmentally sustainable waste management programs and strategies. Despite the increasing importance of sustainable airline waste management, there has been relatively limited research undertaken on this phenomenon. Thus, this study adds some valuable insights to the literature. The study was underpinned by a case study protocol and research framework that followed the recommendations of Stake $(1995,2005)$ and Yin (2017).

As noted in the case study, a key element in Air New Zealand's waste management strategy and policy to manage its wastes has been the collaborative arrangements with its in-flight caterer, LSG Sky Chefs, and New Zealand's Ministry for Primary Industries as part of its "Project Green" waste management program, which was implemented in 2017. The "Project Green waste management program has enabled 40 Air New Zealand inflight products, that were previously disposed by landfill due to biosecurity controls, to be reclassified so that these items could be reused on future flights if removed from an aircraft sealed and untouched. Products approved under the scheme include sealed beverages and snacks (for example, cans of soft drink, packets of cookies, boxes of tea, packets of coffee and sugar sachets). Since its inception, Air New Zealand's "Project Green" waste management program has been implemented in Auckland, Christchurch, and Wellington in New Zealand, as well as at Los Angeles,
California. It is envisaged that the program will be implemented in Chicago, Houston, and San Francisco during 2020. Air New Zealand also works very closely with Auckland International Airport's waste management contractor. This collaborative relationship has enabled Air New Zealand to re-use in-flight products on subsequent flights.

Air New Zealand has placed a very high environmental awareness on how it manages wastes. A key strategy has been to reduce materials at the source, for instance, not offering water bottles on flights under five hours duration. Air New Zealand has also been able to re-use its in-flight catering waste through its collaboration with its inflight caterer and the New Zealand Ministry for Primary Industries. This has diverted wastes that would have been previously been disposed by landfill. Recycling of wastes is another sustainable waste management strategy implemented by Air New Zealand. The airline recycles its wastes wherever possible, for example, PET bottles, office furniture is donated to charities as are uniforms, that present no security risk. The airline has put together a dedicated team whose aim is to raise the awareness of recycling of products wherever possible. Air New Zealand is also highly strategic about who the company purchases products/ materials from and what is purchased to ensure it meets customer, regulatory and sustainability expectations. The airline is also transitioning single-use plastic items to lower-impact alternatives. As a part of its Sustainability Policy, Air New Zealand has set waste disposal targets: zero waste to landfill from Auckland ground sites by end of the 2020 financial year, $75 \%$ diversion from landfill at non-Auckland ground sites by the end of the 2019 financial year, and 
$50 \%$ of domestic jet inflight waste diverted from landfill by the end of the 2019 financial year. These targets are carefully measured, and the data reported in the airline's annual sustainability report.

Each year, Air New Zealand generates a heterogeneous range of organic and inflight wastes. The wastes produced from the airline's in-flight services, include plastic cups, sugar packets, bottled water, plastic toothbrushes, straws, million stirrers, eye mask wrappers, soft drink cans, packets of cookies, boxes of tea, and packets of coffee.

The case study also revealed that Air New key challenge confronted by the airline, in reducing waste to landfill, is the apparent lack of recycling and composting infrastructure available for the airline to dispose of its waste materials to. Consequently, more robust infrastructure located throughout New Zealand, would assist Air New Zealand to keep compostable and recyclable waste out of landfills. In order to address this challenge, Air New Zealand has been investigating the types of products that it purchases to ensure these can be processed in existing New Zealand waste facilities. Other waste management-related challenges include Air New Zealand no longer being able to send the volumes of fabric type used in the company's uniforms to local textile recycling plants. Also, there is only a single New Zealand-based polyethylene terephthalate (PET) firm, which potentially restricts the airline's ability to environmentally dispose of such items.

\section{References}

Ahmed, M. et al. 2020. Wastes to be the source of nutrients and energy to mitigate climate change and ensure future sustainability: options and strategies, Journal of Plant Nutrition 43(6): 896-920.
Air New Zealand. 2015a. Annual data book 2015. Available from internet: <https://www.airnewzealand. com.au/databook>.

Air New Zealand. 2015b. Sustainability report/2015. Available from internet: <https://www.airnewzealand. com.au/sustainability-reporting-and-communication $>$.

Air New Zealand. 2016. Sustainability report 2016. Available from internet: <https://indd.adobe.com/view/ d6f4b228-ae18-4ad4-ae53-f455f798de79>.

Air New Zealand. 2017a. Air New Zealand leads the way with inflight waste. Media Release 4 October. Available from internet: <https://www.airnewzealand.co.nz/ press-release-2017-air-new-zealand-leads-the-waywith-inflight-waste>.

Air New Zealand. 2017b. Sustainability 2017. Available from internet: <https://indd.adobe.com/view/ ba876813-8fcc-4c0a-bff9-bd8dae07b0aa >.

Air New Zealand. 2018. Sustainability report 2018. Available from internet: <https://p-airnz.com/cms/ assets/PDFs?2018-Sustainability-Report.pdf $>$.

Air New Zealand. 2019a. Air New Zealand scores an unprecedented double at 'Oscars of the airline industry'. Media Release 18 January. Available from internet: <https://www.airnewzealand.com.sg/press-release2019-air-nz-scores-double-at-oscars-of-the-airlineindustry $>$.

Air New Zealand. 2019b. Annual data book 2019. Available from internet: <https://indd.adobe.com/ view/55faf230-46c9-4c0a-8568-6cc464e38c78>.

Air New Zealand. 2019c. Sustainability report 2019. Available from internet: <https://www.airnewzealand. com.au/sustainability-reporting-and-communication $>$.

Air New Zealand. 2020a. Air New Zealand project diverts nearly 900 tonnes of inflight waste from landfill. Media Release 17 February. Available from internet: 
<https://www.airnewzealand.com.au/press-release2020-airnz-project-diverts-nearly-900-tonnes-inflightwaste-from-landfill>.

Air New Zealand. 2020b. Operating fleet. Available from internet: <https://www.airnewzealand.com.au/fleet $>$.

Air New Zealand. 2020c. Frequently asked questions. Available from internet: <https://www.airnewzealand. com.au/investor-centre-frequently-asked-questions $>$.

Airside International. 2018. Air NZ accelerates waste reduction project in conjunction with LSG Sky Chefs. Available from internet: <https://www.airsideint. com/air-nz-accelerates-waste-reduction-project-inconjunction-with-lsg-sky-chefs/>.

Awasthi, M.K. et al. 2019. Global status of waste-toenergy technology. In book (eds. Kumar, S., Kumar, R., Pandey, A.) Current developments in biotechnology and bioengineering: waste treatment processes for energy generation. Elsevier, The Netherlands: 31-52.

Baxter, G. 2019. A strategic analysis of Cargolux Airlines International position in the global air cargo supply chain using Porter's Five Forces Model, Infrastructures 4(1): 6.

Baxter, G.; Srisaeng, P.; Wild, G. 2018a. An assessment of airport sustainability, Part 1-Waste management at Copenhagen Airport, Resources 7(1): 21.

Baxter, G.; Srisaeng, P.; Wild, G. 2018b. Sustainable airport waste management: The case of Kansai International Airport, Recycling 3(1): 6.

Blanca-Alcubilla, G. et al. 2019. Airplane cabin waste characterization: knowing the waste for sustainable management and future recommendations, Waste Management 96: 57-64.
Bradley, G. 2019. Lisa Daniell at forefront of Air New Zealand's work to cut environmental footprint, $\mathrm{NZ}$ Herald, 12 January. Available from internet: <https:// www.nzherald.co.nz/business/news/article.cfm?c $\mathrm{id}=3$ \&objectid $=12176125>$.

Brimson, S. 1985. The airlines of the world. Dreamweaver Books, Australia. 255 p.

Chandrappa, R.; Das, D.B. 2012. Solid waste management: principles and practice. Springer, Germany. $414 \mathrm{p}$.

Chang, N.B.; Pires, A. 2015. Sustainable solid waste management: a systems engineering approach. John Wiley \& Sons, USA. 908 p.

Chant, C. 1997. Airlines of the world. Tiger Books International, UK. $111 \mathrm{p}$.

Christenson, T.H. 2010. Introduction. In book (ed. Christenson, T.H.) Solid waste technology and management. John Wiley \& Sons, UK, 1-16.

Cole, C. et al. 2014. Towards a zero waste strategy for an English Local Authority, Resources, Conservation, and Recycling 89: 64-75.

Corsten, M. et al. 2013. The potential contribution of sustainable waste management to energy use and greenhouse gas emission reduction in the Netherlands, Resources, Conservation \& Recycling 77: 13-21.

Creedy, S. 2017. Air New Zealand gets green light to reuse in-flight products. Available from internet: <https:// www.airlineratings.com/news/air-new-zealand-getsgreen-light-re-use-flight-products/>.

Daley, B. 2016. Air transport and the environment. Routledge, UK. 274 p. 
Davies, A.R. 2016. The geographies of garbage governance: interventions, interactions and outcomes. Routledge, UK. 204 p.

Demirbas, A. 2015. Waste management, waste resource facilities and waste conversion processes, Energy Conversion and Management 52(2): 1280-1287.

Duval, D.T. 2005. Tourism and air transport in Oceania. In book (eds. Cooper, C., Michael Hall, C.). Oceania: a tourism handbook. Channel View Publications, UK, 321-334.

El-Mobaidh, A.M.; Taha, M.A.R.; Lassheen, N.K. 2006. Classification of in-flight catering wastes in Egypt air flights and its potential as energy source (chemical approach), Waste Management 26(6): 587-591.

Erickson, L.E. 2016. Foreword. In book (eds. Prasad, M.N.V., Shih, K.). Environmental materials and waste: resource recovery and pollution prevention. Academic Press, $\mathrm{UK}, \mathrm{xxv}$.

European Commission. 2019. Directive 2008/98/EC on waste (Waste Framework Directive). Available from internet: <http://ec.europa.eu/environment/waste/ framework/>.

Fulcher, J.; Scott, J. 2011. Sociology. Fourth Edition. Oxford University Press, UK. 879 p.

Gavine, A. 2017. Air New Zealand striving to reduce inflight waste. Available from internet: <https://www. aircraftinteriorsinternational.com/news/inflightamenities/air-new-zealand-striving-to-reduce-inflightwaste-2.html>.

Gaynor, B. 2015. Air NZ privatisation has paid off for taxpayers. Available from internet: <https:// www.nzherald.co.nz/business/news/article.cfm?c $\mathrm{id}=3$ \&objectid $=11508152>$.
Grant, A. 2019. Doing excellent social research with documents: practical examples and guidance for qualitative researchers. Routledge, UK. 194 p.

Green Air. 2020. Air New Zealand commits to doubling the number of in-flight single-use plastics it will remove this year. Available from internet: <https://www. greenaironline.com/news.php? viewStory $=2620>$.

Green, W.; Swanborough, G. 1975. The Observer's world airlines and airliner directory. Frederick Warne \& Company Limited, UK. 384 p.

Güren, S. 2015. Sustainable waste management. In book (ed. Akkucuk, U.) Handbook of research on developing sustainable value in economics, finance, and marketing. Business Science Reference, USA, 141-156.

Hagmann, C.; Semeijn, J.; Vellenga, D.B. 2015. Exploring the green image of airlines: passenger perceptions and airline choice, Journal of Air Transport Management 43: $37-45$.

Heijungs, R.; Guinée, J.B. 2007. Allocation and 'what-if' scenarios in life cycle assessment of waste management systems, Waste Management 27(8): 997-1005.

Hettiarachchi, H.; Kshourad, C. 2019. Promoting wasteto-energy: nexus thinking, policy instruments, and implications for the environment. In book (eds. Kumar, S., Kumar, R., Pandey, A. Eds.) Current developments in biotechnology and bioengineering: waste treatment processes for energy generation. Elsevier, The Netherland: 163-184.

Holloway, S. 2016. Straight and level: practical airline economics. Third Edition. Routledge, UK. 616 p.

International Air Transport Association. 2020a. Airline cabin waste. Available from internet: <https://www.iata. org/en/policy/environment/cabin-waste/>. 
International Air Transport Association. 2020b. Dossier: Repackaging the regulations. Available from internet: <https://www.airlines.iata.org/ analysis/dossier-repackaging-the-regulations? $\mathrm{ga}=2.88792283 .1559736287 .1582148879$ 720301207.1582148876>.

Jones, P. 2004. Flight catering. Second Edition. Elsevier Butterworth-Heinemann, UK. 319 p.

Kitamura, K. 2019. A conceptual framework for managerial analysis under economic nationalism and globalization: a study of Japanese automakers in the USA. In book (eds. Chandan, H. C., Christiansen, B.) International firms' economic nationalism and trade policies in the globalization era. IGI Global, USA, 35-58.

Kumar, A.; Aswin, A.; Gupta, H. 2020. Evaluating green performance of the airports using hybrid BWM and VIKOR methodology, Tourism Management 76: 103941.

Li, X.D. et al. 2003. Waste reduction and recycling strategies for the in-flight services in the airline industry, Resources, Conservation \& Recycling 37(3): 87-99.

Manahan, S.E. 2011. Fundamentals of environmental chemistry. Third Edition. CRC Press, USA. 1233 p.

Mayer, R.; Ryley, T.; Gillingwater, D. 2012. Passenger perceptions of the green image associated with airlines, Journal of Transport Geography 22: 179-186.

Monios, J. 2016. Institutional challenges to intermodal transport and logistics: governance in port regionalization and hinterland integration. Routledge, UK. 240 p.

Morrell, P.S. 2013. Airline finance. Fourth Edition. Ashgate Publishing Limited, UK. 328 p.

Moynihan, R.; Moynihan, M. 2019. Here's how airlines are fighting against the 6.7 million tons of cabin waste passengers produce every year. Available from internet: $<$ https://www.insider.com/airlines-battle-cabin-trashflights-plastic-alternatives-2019-8>.
Newberry, S. 2011. Whole of government accounting in New Zealand: a review of WGA financial reports from 1993 to 2010, Abacus 47(4): 501-524.

Nordone, A.J. et al. 2009. In book (eds.: Smith, S.R., Cheeseman, C., Blakey, N). Waste management and minimization; Encyclopedia of life support systems. Eolss Publishing, UK, 90-109.

Pharino, C. 2017. Challenges for sustainable solid waste management: lessons from Thailand. Springer Nature Singapore Limited, Singapore. 141 p.

Pires, A. et al. 2019. Sustainable solid waste collection and management. Springer International Publishing, Switzerland. $368 \mathrm{p}$.

Pitt,M.; Smith, A. 2003. Waste management efficiencyat UK airports, Journal of Air Transport Management 9(2): 103-111.

Rand, T.; Haukohl, J.; Marxen, U. 2000. Municipal solid waste incineration: requirements for a successful project. The World Bank, USA. 95 p.

Rahim, A.R.; Baksh, M.S. 2003. Case study method for product development in engineer-to-order organisations, Work Study 52(1): 25-36.

Ramon Gil-Garcia, J. 2012. Enacting electronic government success: an integrative study of government-wide websites, organizational capabilities, and institutions. Springer Science-Business Media, USA. 254 p.

Rathoure, A.K. 2020. Preface. In book (ed. Rathoure, A.K.) Zero waste: management practices for environmental sustainability. CRC Press, USA: xi-xii.

Rueb, E.S. 2019. Airline food waste is a problem. Can banana leaves be part of the solution? Available from internet: <https://www.nytimes.com/2019/10/11/ us/airline-cabin-waste.html>.

Schäfer, A.W.; Waitz, I.A. 2014. Air transportation and the environment, Transport Policy 34: 1-4.

\section{jitte 369}


Scott, J.; Marshall, G. 2009. A dictionary of sociology. Third Edition. Oxford University Press, USA. 816 p.

Seadon, J.K. 2010. Sustainable waste management systems, Journal of Cleaner Production 18(16-17): 16391651 .

Sheward, E. 2006. Aviation food safety. Blackwell Publishing, UK. 379 p.

Smith, L. 2019. This airline is replacing millions of single-use cups with tasty edible ones. Available from internet: <https://www.fastcompany.com/90439655/ this-airline-is-replacing-millions-of-single-use-cupswith-tasty-edible-ones $>$.

Stake, R.E. 1995. The art of case study research. SAGE Publications, USA. 175 p.

Stake, R.E. 2005. Qualitative case studies. In book (eds. Denzin, N.K., Lincoln, Y.S.) The SAGE handbook of qualitative research. SAGE Publications, USA, 443-466.

Trabold, T.A.; Nair, V. 2019. Conventional food waste management methods. In book (eds. Trabold, T., Babbitt, C.W.) Sustainable food waste-to-energy systems. Academic Press, UK, 29-45.

United States Federal Aviation Administration. 2013. Recycling, reuse and waste reduction at airports $\mathrm{A}$ synthesis document. Available from internet: <https:// www.faa.gov/airports/resources/publications/reports/ environmental/media/recyclingsynthesis2013.pdf $>$.
Uz Zaman, A. 2014. Identification of key assessment indicators of the zero waste management systems, Ecological Indicators 36: 682-693.

van Schoor, B. 2017. Fighting corruption collectively: how successful are sector-specific coordinated governance initiatives in curbing corruption. Springer, Germany. 221 p.

Vezich, D. 2017. Air New Zealand to recycle food across flights. Available from internet: <https://www.newshub. co.nz/home/money/2017/10/air-new-zealand-torecycle-food-across-flights.html>.

Yin, R.K. 2018. Case study research and applications. Sixth Edition. SAGE Publications, USA. 352 p.

Young, K. 2020. Air New Zealand celebrates waste reduction achievements. Available from internet: $<$ https://www.inflight-online.com/air-new-zealandcelebrates-waste-reduction-achievements/>.

Zaman, A.; Ahsan, T. 2020. Zero-waste: reconsidering waste management for the future. Routledge, USA. 216 p.

Zhu, D. et al. 2008. Improving municipal solid waste management in India: a sourcebook for policy makers and practitioners. The World Bank, USA. 190 p. 